\title{
FRANCO VS ECO: ECONOMIC TECHNICISMS BETWEEN ADVANTAGES AND DISADVANTAGES
}

\author{
Palumbo Vincenzo and Villani Chiara \\ Lecturer In International Economics. Graduated From The University Of Naples Federico 2. Middle East \\ International Trade Economist \\ http://doi.org/10.35409/IJBMER.2021.3288
}

\begin{abstract}
Born 73 years ago, exactly on December 26, 1945, the day France ratified the Bretton Woods agreements, the CFA franc now disappears to be replaced by the Eco. Opponents and supporters bounce between colonial heritage as an instrument of monetary slavery and an instrument of guarantee for those who adopt it.

This is combined with the question debated several times, which often takes on ideological connotations, relating to the fact that various currents have always seen in the CFA franc the emblem of neo-colonialism for which, however tiring, the adoption of a new single and independent currency it finally appears to them as a concrete step in the direction of real autonomy.
\end{abstract}

Keyword: International Trade, Africa, International Money.

\section{INTRODUCTION}

The CFA is used today in 14 African countries, in all there are about 155 million people and 235 billion dollars of gross domestic product.

The Italian accusation against the CFA is heavy: France would not allow its former African colonies to develop. The media, both French and African, commenting on the news are divided between enthusiastic and dubious tones. For those aligned with Paris policy it would be "historical news", "a decisive turning of the page", "the end of the Françafrique". For the most critical, however, we would be faced with a "coin reorganization of the facade of the old colonial", the "umpteenth sleight of hand of the French father-master", a version of the mantra of the Leopard "everything must change so that everything remains as before "In neo-colonial sauce.

An economic analysis can help to clarify.

\section{CFA : ECONOMIC ISSUES}

The CFA franc can be viewed from multiple angles. And it has advantages as well as disadvantages. And even the accusation of representing only a colonial legacy is not correct. The characteristics of the Franco Cfa are the following: 


\section{International Journal of Business Management and Economic Review}

Vol. 4, No. 04; 2021

ISSN: 2581-4664

- The currency is pegged to the euro according to a fixed parity decided by France (starting from January 1, 2002, the exchange rate was set at 1 euro for 656 CFA) and the convertibility of CFA francs only with the euro.

- The banknotes are printed in the French capital and then sent thousands of kilometers further south to the central banks of the individual states and every three years, the Banque of France pays interest to the countries in question (at a minimum rate set in 2013 at $0.75 \%$ )

- Centralization of foreign exchange reserves at the French central bank: the countries that adopt it are obliged to deposit 50\% of their foreign exchange reserves with the Paris Treasury. This sum is guarded by the French central bank in order to guarantee monetary stability in times of crisis. The gold reserves of African countries are also held in Paris.

- In Africa, it is mainly two regional central banks, BCEAO (based in Dakar, Senegal) and Cemac (in Yaoundé, Cameroon), which supervise the monetary circulation of the CFA franc, but both bodies must reserve seats in the councils of administration to French representatives.

- The member countries of the CFA franc are required to respect the constraint of 3\% in the ratio between deficit and GDP, as laid down for economies in France, Germany or Italy. Should African countries exceed this percentage, sanctions would be triggered

So, since the CFA franc is tied to the euro, its monetary stability is guaranteed as it avoids violent swings for African countries, also in terms of inflation.

The system guarantees African nations the ability to exchange the franc for any other currency and indexation then makes the currency particularly strong, which facilitates imports, for the nations that use it, as well as allowing France to buy African commodities, generally denominated in dollars, in their own currency.

Instead, however, it is local products exported abroad that are penalized as the high value of the euro plays a negative role on the competitiveness of export prices of African countries (especially in the agricultural and mining sectors that have suffered decades of lack of competitiveness).

In addition, the countries of the franc zone are required to have half of their foreign exchange reserves in a special account opened in the accounting registers of the French Treasury. It is from this account, called the "operating account", that most of their foreign operations go through. In return for these reserves, the Treasury has to lend to the central banks in the franc zone as many euros as they need to restore their operating accounts, should they become debtors. In this way, the French Treasury ensures that the level of exchange reserves of the countries of the franc zone is always positive, also allowing to maintain the fixed parity of the CFA franc in relation to the euro. The obligation to transfer half of the reserves to the French Treasury prevents the structural transformations that would be necessary on the Continent, but many economists also recall a certainly not secondary fact: Paris does not earn money thanks to $50 \%$ of the reserves and above 


\section{International Journal of Business Management and Economic Review}

Vol. 4, No. 04; 2021

ISSN: 2581-4664

all it is only the custodian of these sums, the government of Paris, in other words, cannot dispose of them. Furthermore, the fact that it periodically pays an interest rate to African countries certainly represents a considerable gain today, since the market rate is currently much lower than the minimum established.

Other evidence is that the central banks of the franc zone (BCEAO and BEAC). In other words, they are more "issuing institutes", as in the colonial period, than real "central banks". Their powers are rather limited, given that it is the French Treasury that decides on the parity of the CFA franc and on the production of money. The very fact that the banknotes are not manufactured directly in Africa is a mechanism that undoubtedly makes the system not very dynamic and unable to respond to the global economic system but which at the same time allows you to enjoy insurance against the defects of African economic governance.

Another issue that raises many doubts is the imposition on these countries of the budgetary discipline in force in the European Union. Objectively, this limit to be respected reduces the ability to intervene and also the political, economic and social weight of public power. In fact, the 3\% constraint tends to curb funding for government policies, which are already low, and was conceived for highly developed nations such as Germany (328.7 billion euros in public spending in 2017). It is difficult to think that it can be applied in an identical way to macro-economically almost polar opposites ${ }^{1}$.

While it is therefore necessary to accept that the entire system as a whole may in part represent a brake on the development of the economy of African countries, it is also necessary to accept that the same system allows to guarantee a secure framework by facilitating investments by French companies in Africa and finally it acts as a factor of stability, helping the economies of the countries of the area not to be overwhelmed by inflation.

In conclusion, while on the geopolitical front the imbalance that the system implies in terms of freedom in monetary policies is undeniable (even if it is natural to dwell on the fact that African countries retain, at least in theory, the freedom to leave the system as it actually happened for Mauritania and Madagascar) in terms of economic effects, the balance cannot be tipped only by one of the two sides.

\section{FROM FRANCO CFA TO ECO: WHAT CHANGES AND WHAT REMAINS UNCHANGED}

In addition to the name change, the reform provides that:

- The currency remains pegged to the euro (therefore the fixed exchange rate remains, i.e. 1 euro $=655.96$ CFA francs);

- The Bank of France will continue to print, transport and insure the Eco, a service offered for almost 41 million euros per year, paid directly by the BCEAo;

\footnotetext{
${ }^{1} \mathrm{EMU}$ is the result of gradual economic integration and is therefore not an end in itself. EMU was designed to promote sustainable economic growth and a high level of employment through appropriate economic and monetary policies. This includes three main areas: i) implementing a monetary policy with the aim of price stability; (ii) avoid possible spillover effects due to unsustainable public finances, prevent the emergence of macroeconomic imbalances in Member States and coordinate the economic policies of Member States to some extent; iii) to ensure the proper functioning of the internal market.
} 


\section{International Journal of Business Management and Economic Review}

Vol. 4, No. 04; 2021

ISSN: 2581-4664

- The obligation for African countries to deposit 50\% of the reserves in the French Treasury is removed. In fact, the Bank will be able to recover the monetary reserves of these countries from the coffers of the French Treasury;

- Withdrawal of the French representatives from the technical control bodies of the Central Bank of West African States (BCEAO), specifically from the composition of the board of directors and the monetary policy committee, as well as from the EMOA banking commission.

Therefore, the anchor and the fixed exchange rate with the euro remain, together with the protection of France wich passes from "co-manager" to "fiduciary guarantor" of the African currency in the event of a monetary crisis, even if the modalities of this guarantee have not yet been clarified, It only emerged that Paris requires as a counterpart privileged access to the macroeconomic information of the countries of the EMOA. It also follows that the EMU countries will remain under the indirect supervision of the Eurozone authorities as they will monitor the "guarantee" of convertibility provided by France, which will continue to ensure their liquidity in the event of external payment problems. In particular, whenever the BCEAo finds itself in a situation of zero foreign exchange reserves, the French Treasury will be able to continue lending it the desired amounts in French currency.

The membership standards established in Abuja must also be taken into account: the deficit must not exceed 3\%, the annual inflation rate must not be less than 10\%, the countries must have gross reserves capable of financing at least three months of imports and the central bank budget deficit should not exceed $10 \%$ of the previous year's tax revenues.

\section{CONCLUSION}

The "Cfa", linked to the euro, allows stability. But it raises a lot of controversy and for some months the debate has become international.

What would happen if the Eco came into effect? How will the two currencies interact? the conditional is a must. To the many aspects it is necessary to consider the possibility of doubledigit inflation and also that the economic and political instability of several member countries could affect others. For ECO to work, specific conditions must exist, such as the existence of a large and integrated labor market that enables workers to move easily according to employment needs, greater flexibility in prices and wages and greater mobility of employees. capital, necessary elements to eliminate trade imbalances in the region. Furthermore, such a project requires that the countries involved have similar business cycles to avoid shocks.

But the economy is not everything, this theme is between economics and geopolitics.

In fact, the adoption of Eco is in any case an important geo-political step in the revolution underway on the continent. Not to mention the necessary political stability, difficult to guarantee due also and above all to the worsening of the terrorist threat throughout the Sahel region. Indeed, in recent years the danger of international terrorism has slowed down the process of development and union of the various economies. In Africa, nothing is easy. Within the Ecowas, the differences are abysmal. There are countries that have a more stable and less corrupt economy and at the same time there are countries that have a weak economy and very much affected by rampant corruption. There are states that have a good percentage of the population 


\section{International Journal of Business Management and Economic Review}

Vol. 4, No. 04; 2021

ISSN: 2581-4664

with schooling and others where the majority of the population has a very low level of education. A purely economic analysis therefore has the advantages of obtaining objective information but suffers the limits of these profound differences and thinking that Eco alone can solve the economic problems of the region is wrong. Its adoption, as well as its non-adoption, from an exclusively economic point of view, entail benefits but also have evident negative repercussions. Economic science itself has advantages of analysis but at the same time limits in the overall view.

The CFA franc

Also called CFA Senegal or Senegalese franc and pronounced Sefa franc, it is the currency used by 14 African nations, most of which were former French colonies. It belongs to the so-called free zone, which also includes the CFP franc and the Comorian franc. Since joining this currency on a voluntary basis, over the years it has been adopted or abandoned by several countries. It was established with the Bretton Woods agreements of 1945, which sought to regulate economic and monetary relations between the main Western countries after the Second World War.

Eight of these countries make up the West African Economic and Monetary Union (UEMOA) and use the CFA XOF, the other six the Central African Economic and Monetary Community (CEMAC) and use the CFA XAF.

The two versions of the currency have the same fixed exchange rate with the euro and therefore the same value equal to $1 \mathrm{CFA}$ franc $=0.001524$ euro. The fixed exchange rate and convertibility are guaranteed by the Bank of France.

The currency offers the countries that have adopted it a guarantee for international trade, being anchored to the euro and guaranteed by France. However, it has the disadvantage of having too strong a value for these developing countries, which therefore see their exports penalized.

\section{REFERENCES}

Africa Watch: look at the geo - economy of a growing continent, ispionline.it

How the CFA franc hinders the development of Africa, www. agi.it, 22 gennaio 2019

Andrea de Georgio, journalist: Africa gets rid of the CFA franc but not of French control, www.internazionale.it 28/05/2020

Giusy Baioni Eco (2020) the currency of the West African economic community will arrive in January. It will replace (in part) the CFA franc - 08/07/2019

West Africa (2019) goodbye to the CFA franc: the new currency will be called ECO, IL Sole 24ORE

Andrea De Georgio (2020) Journalist: Africa Gets Rid of the CFA Franc But not of French Control, - www.Internazionale.IT

Zupi Marco Is the truth of the story in the details? From the CFA franc to the Eco - 17/01/2020

Anais Ginori, France retires the CFA franc, the currency of the colonies REPUBLIC 20/05/2020 